\title{
Determinants of Women Access and the Extent of Access to Land Among Small-Scale Farmers in Machakos County, Kenya: A Double-Hurdle Approach
}

\author{
Veronica N. Kariuki $^{{ }^{*}}$ Oscar I. Ayuya ${ }^{1} \quad$ John M. Nduko $^{2}$ \\ 1.Department of Agricultural Economics and Agri-Business Management, Egerton University, P.O Box 536- \\ 20115, Egerton, Kenya \\ 2.Department of Dairy and Food Science and Technology, Egerton University, P.O Box 536-20115, Egerton, \\ Kenya
}

\begin{abstract}
The aim of this paper is to evaluate the determinants of women access and the extent of access to land. The study used cross-sectional data from 384 randomly selected small-scale women farmers from Machakos County, Kenya. Using double hurdle (DH) model, we found that marital status, household size, the value of productive assets, credit borrowed, extension contacts, farmers' groups and social influence from family members had a positive and significant influence on women access to land. However, the spousal age gap, market distance and social influence from friends/peers had a negative influence on the probability of women having access to land. To improve women access to land, the findings imply that women need to be motivated to join and participate in farmers' groups through which they can gain access to extension information and credit. In addition, women farmers should be sensitized on the need to invest in farm productive assets. Importantly, the government can aid in improving crucial infrastructures and promoting girl-child education since education empowers women and inhibit early marriages. Keywords: Women, small-scale farmers, access to land, double hurdle model, Kenya
\end{abstract}

DOI: $10.7176 / \mathrm{JESD} / 10-7-04$

Publication date: April $30^{\text {th }} 2019$

\section{Introduction}

Land in most developing countries is one of the most valuable natural resource required for the creation of wealth. Having access to land brings economic power, which is usually the basis of social and political power (Muyanga and Jayne, 2014). Land is the mainstay of Kenya's economy since over $80 \%$ of the Kenyan population derive their livelihood from agriculture and agriculture contributes about 32.6\% to the Gross Domestic Product (Kirimi et al., 2013; Muraoka et al., 2014; KNBS, 2017). Land access can be defined as the process by which people individually or collectively gain rights and opportunities to control and utilize land on a temporary or permanent basis (Khalid et al., 2015). Access to land is a crucial issue especially among small-scale farmers because it is a valuable asset that is used for household food production as well as a key factor for shelter and community development. Thus, it downgrades their vulnerability to hunger, malnutrition and poverty as well as enhances their participation in productive activities (Gyau et al., 2014; Menon et al., 2014; Doss et al., 2015). Therefore, its ownership, allocation, distribution and utilization is of great concern to most Kenyans especially the small-scale farmers. This is because the way land is owned, used, and exchanged has extensive implications on the productivity of that land, equity, and overall economic growth (Jin and Jayne, 2013).

Small-scale farmers constitute the bulk of agricultural producers in Kenya and produce about $63 \%$ of the total food that is consumed in the country ( FAO, 2015). However, their productivity is hampered by limited access to land, low input use, insufficient and poorly maintained market infrastructures, limited access to extension services, use of obsolete technology, and climate change (Kirimi et al., 2013). According to the World Bank (2012), women in many developing countries are facing gender discrimination in terms of access to productive resources, which is fundamentally driven by gendered customary institutions, perceptions, and norms. However, women involvement in agriculture improves household livelihoods as well as social welfare among rural small-scale farmers through mitigation of hunger, food insecurity, and poverty. (Doss et al. 2011; Doss et al., 2015; Mishra and Sam, 2016).

Gender, agricultural and development issues continue to create interest among researchers and policymakers in developing countries (Meinzen-dick et al., 2010; Ndiritu et al., 2014; Lambrecht, 2016). This is because women play a key role in the agricultural sector and the economy in general. Therefore, the Government of Kenya has embarked on several strategies aimed at improving gender equality, for instance, through the constitution. In the 2010 constitution of Kenya, there are several provisions that guarantee the rights of women to own property including land. In addition, several laws in the constitution, for example, family, inheritance, and marriage laws provide other ways of enhancing gender equality in the country.

Despite women being the driving force behind subsistence farming and food security, which play an integral role in the household well-being and the economy as a whole, they still cannot fully exercise their right to property 
especially land (Kassie et al., 2014). A plethora of literature exists on land access especially in developing countries (Kassie et al., 2014; Menon et al., 2014; Odoemelam et al., 2014; Lambrecht, 2016). However, the role of socio-economic and institutional factors in influencing access and the extent of women access to land is not clear in the empirical literature. Furthermore, previous studies involving a two-step analysis have used a selection model, for example, Heckman Selection model which assumes incidental truncation but this study employed a Double hurdle model. This is because the Double-Hurdle model is used to correct for potentially biased and inconsistent coefficient estimation due to sample selection bias (Greene, 2002). Other studies have used a Tobit regression model but this study prefers the double hurdle model since the Tobit model is restrictive in nature. It is therefore on this background, that this study is geared towards filling this knowledge gap. The objective of the study is to evaluate the determinants of women access and the extent of access to land and thus, the double-hurdle model proposed by Cragg (1971) was used to analyze this objective.

Using double hurdle model, this study seeks to contribute to the existing literature in the following ways: first, this model has enabled us to determine the factors influencing access and the extent of women access to land. The variables affecting access and those affecting the extent of access to land may differ and that why the double hurdle model was more preferred since it is not restrictive in nature. The knowledge from this study is of great relevance to researchers and policy makers at national and county level in order to formulate policies and programs that will enhance gender equality, especially in access to productive resources. This is because productive resources constitute a crucial engine for the country's economy as well as a considerable source of livelihoods for the majority of small-scale farmers in the country. Secondly, the study provides new evidence from some policyrelevant variables such as social influence and the spousal age gap (age difference between spouses).

The rest of the paper is structured as follows: section two provides the methodology. This is followed by section three which covers the analytical framework of the Double Hurdle model (DH). Section four presents the results of the empirical analysis and finally, section five summarizes the key findings and draws policy implications.

\section{Methodology}

2.1 Study area

The study was carried out in Machakos County, Kenya in the month of November 2017. The County is elevated to a height of 790 to $1594 \mathrm{~m}$ above sea level and the whole county covers an area of $6208.2 \mathrm{Km}^{2}$. It experiences average annual temperatures that vary between $18^{\circ} \mathrm{C}$ and $29^{\circ} \mathrm{C}$ during the year.

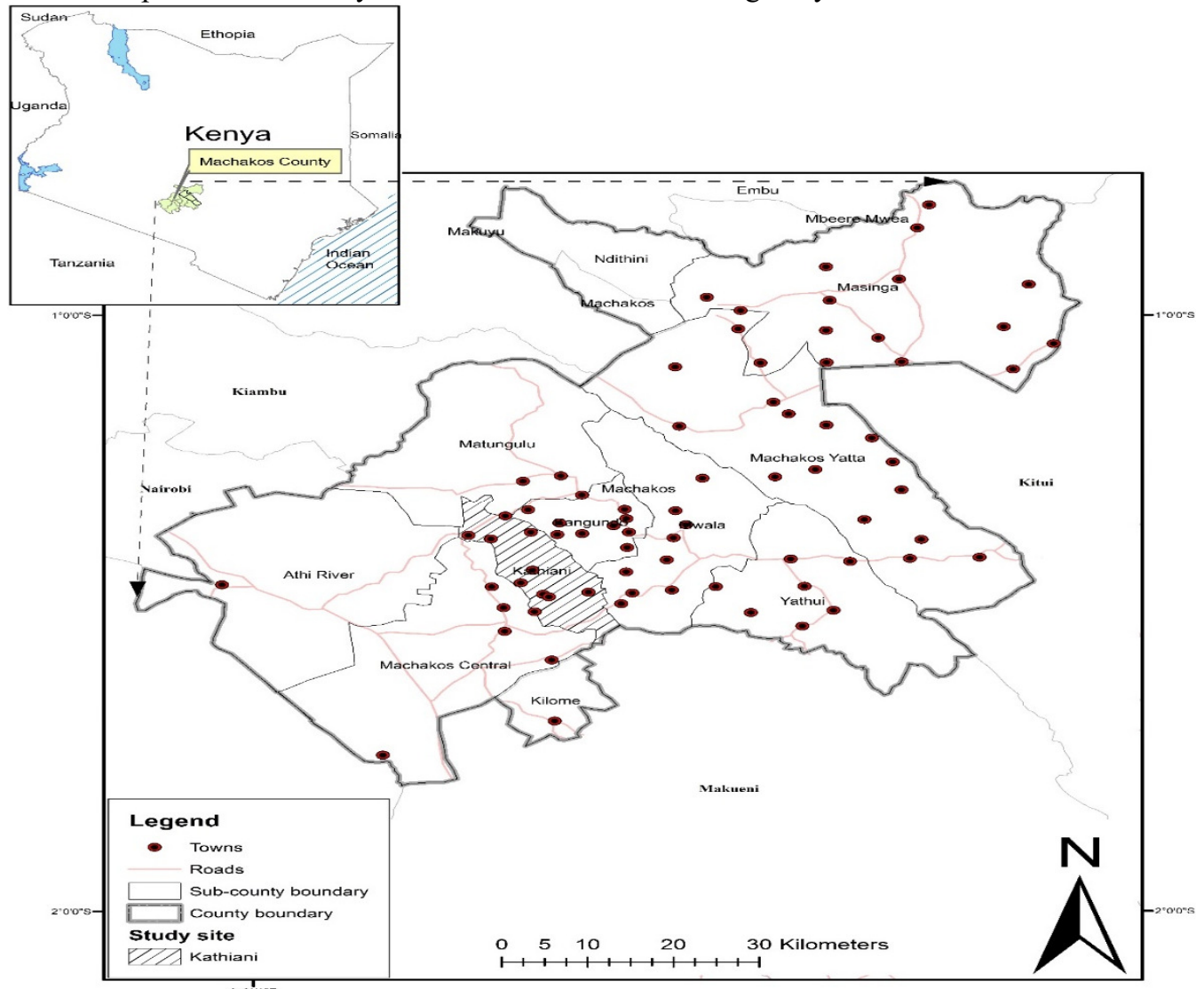

Figure 1: Location of study site in Machakos County, Kenya Source: World Resource Center, 2017 
The average annual rainfall in the county is unreliable and unevenly distributed and ranges between $500 \mathrm{~mm}$ and $1300 \mathrm{~mm}$ (GoK, 2013). The county experiences both long and short rains. Long rains are usually anticipated in the months of March to May, which is eventually followed by a cold season usually during July. The short rains fall between the months of October and December. Since the county experiences erratic and unpredictable rains it is therefore, conducive for growing cash crops like coffee, mangoes, avocados, and pineapples and the main food crops grown include; maize, beans, pumpkins, pigeon peas, and cassava. A large number of small-scale farmers in this county rely on rain-fed agriculture due to the unreliability of the rain and this results to food security problems in the largest part of the county (KNBS, 2017). Livestock rearing which is done in open fields is also a major economic activity in most parts of the County. Small-scale farmers in the county engage mostly in goat farming, sheep rearing, beef production, poultry keeping as well as bee farming.

\subsection{Sampling and data collection}

The sample consisted of small-scale women farmers who were selected using a multistage sampling technique. The first stage entailed purposive sampling of Kathiani Sub-County and then two wards, that is, Kathiani Central and Mitaboni. In stage two, 3 villages in Mitaboni ward were selected out of 6 villages and 2 villages in Kathiani central ward out of 5 villages using simple random sampling. Then, using a household source list obtained from Sub-County agricultural offices, simple random sampling was employed to select 78 households with women farmers per village with the help of local extension officers. The survey was carried out in the month of November 2017 and in total, 384 small-scale women farmers were interviewed. Well trained enumerators with the knowledge of local dialect were used to administer the semi-structured questionnaires to the sampled women farmers.

The study used primary data which was sourced through face to face interviews with the aid of a semi-structured questionnaire. Before launching the actual data collection process, a pilot study was carried out to determine the suitability and validity of the questionnaire on a small sample with similar baseline characteristics as the actual sample population. Data collected in the actual survey included information on household and women demographic, socio-economic and institutional characteristics, number and size of plots accessed by women, women social influence, information sources, and information on household nutrition.

\section{Analytical Framework}

\subsection{Modeling the determinants of women access and the extent of access to land}

To evaluate the factors influencing women access and the extent of access to land a Double Hurdle (DH) model originally formulated by Cragg (1971) was applied. Other studies that have applied this model include; Jones (1989), Pudney (1989), Newnan et al. (2003), Eakins (2016) and Hazarika et al. (2016). DH model was preferred because the extent of women access to land in this study can be expressed as a two-step decision since in the first hurdle, women farmers decide whether or not to have access to land. Then, conditional on the first decision being positive, they decide the extent of access to land in the second hurdle (the number of acres of land to utilize and control). Furthermore, some women farmers did not have access to land given our definition of land access in terms of user rights and control rights, thus resulting in some values being zero which are attributable to economic reasons. Therefore, a corner solution model was more preferred than a selection model. Commonly used corner solution model is a Tobit regression model (Tobin, 1958). However, one drawback of a Tobit regression model is that it is restrictive in nature, as it supposes that the decisions to access to land and the size of land accessed are determined by the same process. Therefore, a more flexible model was preferred which is the Double Hurdle model. The two hurdles of the DH model were conditioned by institutional and socio-economic factors. A different latent variable was used to model each step in the double-hurdle model, with the probit regression model determining the probability that a farmer has access to land and then a truncated normal regression model determining the extent of access to land. Eakins (2016) specified the model as follows;

$$
\begin{aligned}
& y_{i 1}^{*}=W_{i} \alpha+\mu_{i} \\
& y_{i 2}^{*}=X_{i} \beta+v_{i} \\
& y_{i}=X_{i} \beta+v_{i} \\
& y_{i}=0
\end{aligned}
$$$$
\text { Access to land or not }
$$$$
\text { Extent of land access }
$$

Access to land or not

$$
\text { If } \mathrm{y}^{*}{ }_{\mathrm{i} 1}>0 \text { and } \mathrm{y}^{*}{ }_{\mathrm{i} 2}>0
$$

Where $y_{i 1}^{*}$ is a latent variable describing whether the farmer has access to land or not and $y_{i 2}^{*}$ is a latent variable describing the extent of access to land and $\mathrm{y}^{*}$ is the size of land that is accessed by a woman while $\mu_{\mathrm{i}}$ and $\mathrm{v}_{\mathrm{i}}$ are the corresponding error terms following a normal distribution and assumed to be independent, $U_{\mathrm{i}} \sim \mathrm{N}(0,1)$ and $v_{i} \sim \mathrm{N}$ $\left(0, \partial^{2}\right)$. Carroll et al. (2005) estimated the Double Hurdle model using the maximum likelihood estimates as follows; 
$L\left(\alpha, \beta, \sigma^{2}\right)=\prod_{0}\left[1-\Phi\left(w_{i}^{\prime} \alpha\right) \Phi\left(\frac{x_{i}^{\prime} \beta}{\sigma}\right)\right] \times \prod_{1}\left[\Phi\left(w_{i}^{\prime} \alpha\right) \sigma^{-1} \phi\left(\frac{y_{i}-x_{i}^{\prime} \beta}{\sigma}\right)\right]$

From equation 2, $\Phi_{\text {and }} \phi$ are the standard normal cumulative distribution function and density function respectively. Tobit regression model is nested in the DH model. Therefore, a likelihood ratio (LR) test was used to determine the more preferred model between the DH and a Tobit model. To assess the impact of independent variables on the extent of access to land, it was essential to evaluate the marginal effects of the significant variables. According to Mutlu and Gracia (2006), the probability of accessing to land for each individual woman was estimated as follows;

$$
P\left[y_{i}>0 / x\right]=\Phi\left(\frac{x_{i} \beta}{\sigma_{i}}\right)
$$

While the conditional expected size of land accessed was estimated as follows;

$$
E\left[y_{i} / y_{i}>0, x\right]=x_{i} \beta+\sigma_{i}\left(\frac{\phi\left(\frac{x_{i} \beta}{\sigma_{i}}\right)}{\Phi\left(\frac{x_{i} \beta}{\sigma_{i}}\right)}\right)
$$

Similarly, the unconditional expected size of land accessed was estimated as follows;

$$
E\left[y_{i} / x\right]=P\left[y_{i}>0 / x\right] * E\left[y_{i} / x, y_{i}>0\right]
$$

The conditional expectation and the probability of a positive value of $y_{i}$ are estimated by decomposing the unconditional expectation. The average partial effect of each independent variable was estimated following a procedure proposed by Burke (2009). Equation (3) was used to estimate the partial effect on the probability that $y>0$ (APE). While differentiating equation (4) with respect to each explanatory variable, yielded the average effects on the extent of women access to land conditional on a woman farmer having access to land (CAPE). To calculate the partial effect on the unconditional expected value of $y$ (UAPE), equation (5) was differentiated with respect to relevant explanatory variables.

The description of the variables used in the analysis is presented in Appendix 1. The variables were drawn from previous related studies in developing countries (Kirimi et al., 2013; Kassie et al., 2014; Menon et al., 2014; Muraoka et al., 2014; Ndiritu et al., 2014; Mishra and Sam, 2016). The variables were analyzed using $t$-statistics for continuous variables and chi-square statistics for categorical variables. However, social influence was first analyzed using factor analysis. This is because social influence had seven items which were designed and answered using a five-point Likert scale, ranging from strongly disagree to strongly agree. To determine the reliability of the seven items used to measure social influence, Cronbach's alpha coefficient was evaluated (MacKenzie et al., 2011). The obtained value was greater than the recommended value of 0.7 (it was 0.91), suggesting that the items were relatively reliable. Moreover, the Kaiser-Meyer-Olkin (KMO) test was conducted so as to check whether the data collected was appropriate for factor analysis. The value obtained for KMO was 0.84 meaning the sample was adequate and appropriate for factor analysis. The results are presented in Appendix 2. Social influence was found to be significant in explaining women access to land. After the analysis, the social influence consisted of two dimensions: one item related to family members and the other item related to the peers/friends. Social influence from family members had a positive influence on women access to land whereas, social influence from peers had a negative influence on the same.

\section{Results and discussion}

\subsection{Preliminary diagnostics of the variables to be used in the econometric analysis}

Preliminary diagnostics for statistical problems of heteroskedasticity and multicollinearity were conducted to all variables used in the Double Hurdle model. To detect heteroskedasticity for all hypothesized regressors, a white test was used and the results are presented in Appendix 3. The results indicated the presence of heteroskedasticity since a chi-square of 277.41 was significantly large. To counter this problem, robust standard errors were used in all analyses. Multicollinearity is a state of very high inter-correlations among the independent variables and was tested using the variance inflation factor (VIF) for all continuous variables and pairwise correlation test for all categorical variables. The results for continuous variables are presented in Appendix 4 and they confirmed that there was no serious linear relationship among the continuous regressors tested since VIF values were less than 
10. For categorical variables, the results are presented in Appendix 5. Similarly, the results confirmed that there was no serious linear relationship among the categorical regressors because the pairwise correlation coefficients were less than 0.75 in all cases.

\subsection{Descriptive statistics}

Descriptive statistics for small-scale women farmers are presented in Table 1. The selected sample consisted of $69.4 \%$ of women who had access to land while $30.6 \%$ of the women did not have access to land.

Table 1: Descriptive statistics for small-scale women farmers

\begin{tabular}{|c|c|c|c|c|}
\hline \multirow[t]{2}{*}{ Variables } & Access to land & \multicolumn{2}{|l|}{ No access to land } & \multirow[b]{2}{*}{$t$-value } \\
\hline & Mean & \multicolumn{2}{|l|}{ Mean } & \\
\hline Age & $47.05(0.87)$ & \multicolumn{2}{|l|}{$41.93(1.31)$} & $-3.205 * * *$ \\
\hline Spousal age gap & $4.02(0.25)$ & \multicolumn{2}{|l|}{$5.41(0.34)$} & $3.214 * * *$ \\
\hline Schooling years & $9.34(0.24)$ & \multicolumn{2}{|l|}{$9.19(0.29)$} & -0.356 \\
\hline Household size & $4.44(0.08)$ & \multicolumn{2}{|l|}{$4.14(0.10)$} & $-2.130 * *$ \\
\hline Household farm size & $1.31(0.06)$ & \multicolumn{2}{|l|}{$0.94(0.07)$} & $-3.586 * * *$ \\
\hline Agricultural assets value ('000) & $5.98(0.42)$ & \multicolumn{2}{|l|}{$4.60(0.61)$} & $-1.853 *$ \\
\hline Off-farm income ('000) & $46.95(3.75)$ & \multicolumn{2}{|l|}{$35.69(5.70)$} & $-1.656^{*}$ \\
\hline Remittances ('000) & $11.10(1.20)$ & \multicolumn{2}{|l|}{$7.41(1.44)$} & $-1.801 *$ \\
\hline Market distance (walking min) & $21.71(0.84)$ & \multicolumn{2}{|l|}{$29.56(1.61)$} & $4.750 * * *$ \\
\hline Amount of credit ('000) & $7.03(0.99)$ & \multicolumn{2}{|c|}{$0.38(0.18)$} & $-4.397 * * *$ \\
\hline \multirow[t]{3}{*}{ Extension contacts } & $1.43(0.10)$ & \multirow{2}{*}{\multicolumn{2}{|c|}{$\begin{array}{l}0.43(0.10) \\
\text { Access to land }(\%)\end{array}$}} & $-6.091 * * *$ \\
\hline & & & & \\
\hline & Description & Yes & No & $C h i^{2}$-value \\
\hline \multirow[t]{2}{*}{ Marital status } & Married & 75.4 & 94.9 & $20.62 * * *$ \\
\hline & Otherwise & 24.6 & 5.1 & \\
\hline \multirow[t]{3}{*}{ Sources of information } & Others farmers & 55.97 & 88.98 & $41.263 * * *$ \\
\hline & Farmers groups & 25.37 & 3.39 & \\
\hline & Extension agents & 18.66 & 7.63 & \\
\hline Number of observations & & 266 & 118 & \\
\hline
\end{tabular}

Notes: ***,**, and $*$ indicate the level of significance at $p<0.01,0.05$, and 0.1 , respectively and figures in parenthesis are robust standard errors.

From Table 1, women who had access to land had a higher mean age than those who did not have access to land. In terms of the spousal age gap, women who had access to land had a narrower age gap with their spouses as compared to their counterparts. In general, women who had access to land had larger household size and household farm size, earned more off-farm income as well as received more remittances than their counterparts. In addition, they had agricultural assets of higher value, received more credit and extension services and were closer to the markets than those women who did not have access to land. A high proportion $(94.9 \%)$ of the women farmers who did not have access to land were married whereas, $25.37 \%$ of women who had access to land used farmers' groups as their main source of information.

\subsection{Effect of socio-economic and institutional factors on women access to land}

Double hurdle model was used to determine factors influencing women access and the extent of access to land; however, the appropriateness of this model against a Tobit regression model was checked using a likelihood ratio test. The likelihood ratio statistic was $100.80(p=0.000)$, convincingly rejecting the null hypothesis in favor of Tobit specification. This is an indication of the existence of two separate decision-making steps in which individuals make independent decisions regarding access and the extent of access to land. The log pseudolikelihood of the DH model was -359.62 and the model was found to be strongly significant at $1 \%$ level with a Wald Chi-square value of $110.07(p=0.000)$. Average partial effects were used in explaining the effects of independent variables on the predicted values since they can be interpreted with ease than the model coefficients. The results of the average partial effects of independent variables on three quantities of interest, that is, the probability of a woman having access to land (APE), the expected number of acres accessed given that the woman has access to land and the expected number of acres accessed by the woman (UAPE) are presented in Table 2. The standard errors for the Average Partial Effects were acquired using the delta method as proposed by Burke (2009). Several variables were found to be significant in explaining access and the extent of access to land.

Spousal age gap had a negative influence on the probability of women access to land and was significant at $10 \%$. An age difference of 1 year between spouses reduced the likelihood of a woman having access to land by $0.9 \%$. Therefore, women with a higher age difference with their spouses were less likely to have access to land. This possibly because spouses who are of similar age have relatively same reasoning ability which may have a positive influence on women access to land. However, male spouses who are older than their female spouses tend 
to dominate when key decisions are made in the household thus, depriving women a chance to contribute effectively in decision making and this may have a negative influence, especially in women access to land. Kritz and Adebusoye (1999) found that the spouse age gap had a negative effect on women's decision making authority regarding household issues, for example, agricultural-related decisions as well as household expenditure decisions.

The probability of women who were married having access to land was $23.3 \%$ lower than that of women who were not married (single, divorced, and deceased), holding all other factors constant. Moreover, the Unconditional Average Partial Effects (UAPE) indicated that on average, the extent of access to land for women who were married was relatively lower as compared to those who were not married by 0.269 acres. Women who are not married are able to make rational decisions because they are the sole providers of their families and this may have a positive influence in terms of access to land. In addition, for married couples, male spouses in most cases normally dominate when household decisions are made thus leaving their spouses with no or limited control over their agricultural land. In some communities, single women may have access to land through their father's inheritance or through renting or purchasing. Moreover, deceased women may have access to land through their husbands' inheritance whereas, divorced women may have access to land through property sharing after the divorce.

Household size had a positive influence on the probability of women access to land at $10 \%$ significance level. This implies that, if household size increases by one member it would increase the probability of a woman having access to land by $2.8 \%$, ceteris paribus. Household size as a proxy for labor availability may influence women access to land. This is plausible because the majority of small-scale farmers in Kenya use family labor and thus larger household size guarantee labor availability and this may possibly motivate women farmers in those households to acquire more land for farming. In addition, households with more members are associated with a higher demand for agricultural land since their food requirement is also high compared to households with fewer members. The results are in collaboration with those of Odoemelam et al. (2014), who found that households with more members act as a driving force for women to acquire more land for farming since they have a helping hand in the farm.

Table 2: Average Partial Effects and Unconditional average effects of the DH model

\begin{tabular}{|c|c|c|c|c|}
\hline \multirow[b]{2}{*}{ VARIABLES } & \multicolumn{4}{|c|}{ FIRST HURDLE } \\
\hline & APE & SE & UAPE & SE \\
\hline \multicolumn{5}{|l|}{ Socio-economic factors } \\
\hline Age & 0.001 & 0.002 & -0.000 & 0.002 \\
\hline Spousal age gap & $-0.009 *$ & 0.005 & 0.003 & 0.005 \\
\hline Marital status & $-0.233 * * *$ & 0.079 & $-0.269 * * *$ & 0.074 \\
\hline Schooling years & -0.008 & 0.007 & -0.020 & 0.006 \\
\hline Household size & $0.028 *$ & 0.015 & 0.024 & 0.016 \\
\hline Household farm size & 0.036 & 0.027 & $0.345 * * *$ & 0.041 \\
\hline Log value of agricultural assets & $0.036^{* *}$ & 0.018 & $0.048 * *$ & 0.018 \\
\hline Log off-farm income & -0.003 & 0.005 & $-0.013 * * *$ & 0.005 \\
\hline Remittances & 0.005 & 0.005 & $-0.012 * *$ & 0.005 \\
\hline \multicolumn{5}{|l|}{ Institutional factors } \\
\hline Market distance & $-0.004 * * *$ & 0.001 & $-0.004 * * *$ & 0.001 \\
\hline Amount of credit & $0.025 * * *$ & 0.007 & $0.020 * * *$ & 0.007 \\
\hline Extension contacts & $0.036^{* *}$ & 0.017 & $0.061 * * *$ & 0.018 \\
\hline \multicolumn{5}{|l|}{ Social influence } \\
\hline Social influence from family members & $0.063 * * *$ & 0.023 & $0.103 * * *$ & 0.026 \\
\hline Social influence from friends/peers & $-0.047 * *$ & 0.022 & $-0.101 * * *$ & 0.020 \\
\hline \multicolumn{5}{|l|}{ Sources of information } \\
\hline Other farmers ${ }^{1}$ & $0.140 *$ & 0.078 & 0.065 & 0.074 \\
\hline Extension agents $^{1}$ & 0.067 & 0.063 & 0.015 & 0.060 \\
\hline Number of observations & 384 & & & \\
\hline Wald $\operatorname{Chi}^{2}(16)=$ & 109.86 & & & \\
\hline Prob. $>C h i^{2}=$ & 0.000 & & & \\
\hline Log pseudo likelihood & -165.267 & & & \\
\hline
\end{tabular}

stand for Average Partial Effects and Unconditional Average Partial Effects respectively. SE stands for standard errors calculated using the delta method. 1=base category which is farmers' groups.

The value of productive asset owned by women had a positive influence on their probability of having access to land and was significant at $10 \%$. The results indicated that an increase in the value of assets owned by the woman by one Kenya Shilling increased the probability of the woman having access to land by $3.6 \%$, all other factors held constant. In addition, the UAPE indicated that the value of productive assets owned by the woman 
had a positive influence on the number of acres accessed by the woman. The value of productive assets is a proxy for wealth. Asset endowment improves farmers' liquidity position thereby ensuring that they are able to purchase or hire land for agricultural purposes with ease. In addition, asset ownership increases women bargaining power in the household and thus, they are more likely to engage in the household decision-making process. Johnson et al. (2016) found that assets ownership was positively related with women involvement in the household decisionmaking process as well as the share of household land over which they had an influence.

The effect of distance to the input and output market (measured in terms of walking minutes) on the probability of women access to land was found to be negative and significant at $1 \%$ level. Precisely, an increase in time taken to reach the market by 1 minute reduced the probability of a woman having access to land by $0.4 \%$, holding all other factors constant. Moreover, UAPE indicated that the extent of access to land declines with distance to the market. This implies that women who are closer to the market are more likely to have access to land than those who are far away from the market. Proximity to markets reduces transaction costs associated with agriculture. This is because nearness to the market enables women farmers to access market information, credit institutions as well as slashes the transaction costs linked with buying agricultural inputs and transporting farm output to the market. Menale et al. (2010) noted that besides from affecting access to the market, the distance can also affect the accessibility of market information and credit institutions thus having a negative relationship especially in terms of access to land by women.

The amount of credit borrowed in the last three years was found to have a positive effect on the probability of women having access to land and it was significant at $1 \%$ level. This implies that a $1 \%$ increase in credit borrowed in the last three years increased the probability of a woman having access to land by $2.5 \%$, ceteris paribus. The UAPE also indicated that on average, credit borrowed had a positive influence on the extent of women access to land and was significant at $1 \%$ level. The amount of credit borrowed enables the farmer to cater for all the transaction costs associated with farming, especially when renting or buying land. It also increases the capital base of the women farmers thus reducing cash constraints associated with farming. Therefore, it enables them to finance a host of agricultural activities like paying for labor as well as buying the required inputs. Jin and Jayne (2013) found that land purchases and renting requires a huge investment in terms of finances and thus, small-scale farmers who have access to credit may be at an advantaged state.

The number of contacts with extension agents had a positive and significant influence on the probability of women having access to land at $10 \%$. One annual contact with extension agents increased the probability of a woman having access to land by $3.6 \%$, ceteris paribus. The unconditional influence (UAPE) of the number of contacts with extension agents on the extent of women access to land is estimated to be 0.061 acres. The results suggest that women access to land could be motivated by frequent contacts with extension agents. This is because through their contacts with extension agents the women farmers are able to acquire technical skills and knowledge which apparently motivates them to acquire land for subsistence and commercial farming. Knowledge gained through receiving extension services, therefore, plays an imperative role in women access to land. This is in agreement with the study by Baloch and Thapa (2016) who concluded that access to extension services increases farmers' knowledge and skills in agriculture which enhances their access to land as well as improves their agricultural productivity.

Social influence from family members had a positive influence on the probability of women having access to land and was significant at $1 \%$ level. Therefore, those farmers who experienced social influence from their family members in terms of access to land had a higher likelihood of having access to land than those who did not experience any influence from their family members. This implies that women whose family believe that women should have access to land are more likely to have access to land than their counterparts. Gyau et al. (2014) argued that women access to land depends mostly on customary laws as well as individual families. Adams et al. (2017) found that the influence of family members and peers is positively related to consumer decisions which in this case is the decision of having access to land or not. However, social influence from friends or rather peers had a negative and significant influence on the probability of women access to land at $5 \%$ level. Moreover, it had a negative influence on the extent of access to land in both conditional and unconditional levels. The influence of friends tends to affect consumers decisions. Zaki et al. (2011) found that the behavior of the people can have a significant impact on the behavior of other people since people tend to modify their behavior in order to suit with other people.

With regard to the main source of agricultural information, women farmers who used farmers groups as their main source of agricultural information increased their probability of having access to land by $14.0 \%$ as compared to those who received agricultural information from other farmers. Women farmers who were members of a farmers group had a higher probability of accessing land than those who did not belong to any group because of influence from other women farmers who had access to land in the group. Farmer groups are also important channels through which women farmers have access to service providers and this helps farmers in acquiring agricultural skills and knowledge. In addition, group membership is expected to help women farmers in mitigation of problems associated with market imperfections since it enhances farmers' bargaining power as well as enables 
them to enjoy economies of scale. For example, when women farmers are in groups they can lobby for support services like loans that could facilitate the acquisition of land for farming.

\subsection{Effect of socio-economic and institutional factors on the extent of women access to land}

The effect of socio-economic and institutional factors on the extent of women access to land was determined in the second hurdle/tier of the DH model using a truncated normal regression model. Conditional and unconditional average partial effects (CAPE and UAPE) for the second hurdle are presented in Table 3. Household farm size had a positive influence on the extent of women access to land and it was significant at $1 \%$. For women who had access to land, an increase in household farm size by one acre increased their expected size of land accessed by 0.424 acres. Women rely mostly on land accessed through inheritance and therefore when household farm size increases it is expected that their extent of access to land will increase. This is because households with bigger land size may be willing to allocate the woman land to do her agricultural activities as compared to households with smaller sizes of land.

For women who had access to land, an increase in off-farm income reduced their extent of access to land. UAPE also indicated that off-farm income had a negative effect on the extent of women access to land. This is perhaps due to farmers' involvement in off-farm activities, which improve their household income and thus, they tend to have less time for farm-related activities. Off-farm income plays a fundamental role in enhancing household income diversification and for this reason, there is no motivation for women farmers to access more land for agriculture since they have alternative sources of income. Mathenge et al. (2014) argued that engaging in off-farm activities divert time and effort away from agricultural-related activities which reduces farm productivity and women access to land. On the contrary, previous studies (Rao and Qaim, 2011; Woldeyohanes et al., 2016) concluded that higher off-farm incomes promote smallholder commercialization of agriculture if used as a source of liquidity for farm investments and this may eventually lead to women having access to more land for agriculture.

With regard to remittances, an increase in the amount of remittances that the woman received in the last one year reduced their extent of access to land. This implies that given that the woman had access to land, an increase in remittances by one Kenya Shilling reduces the expected size of land accessed by 0.022 acres. Remittance income is normally considered as an alternative for farming income and off-farm income. Households in which the woman receives internal or external remittances from friends and/or relatives tend not to concentrate on accessing more land for farming. This is possible because they have other non-farm sources of income which can cater for their household needs. This is consistent with a study by Jack et al. (2013) who argued that remittances constitute a crucial component of rural household income and are used for different purposes which are in line with production and consumption. On the contrary, Kikulwe et al. (2014) found that remittances contribute significantly to the commercialization of agriculture and thus enhance women access and the extent of access to land.

Social influence from friends had a negative effect on the extent of women access to land and was significant at $1 \%$. For women who had access to land, social influence from friends reduced their expected size of land accessed by 0.083 acres. According to Adam et al. (2017), social influence refers to the extent to which members of a social network influence one another's behavior and experience social pressure to perform particular behaviors. The influence of friends tends to affect consumers decisions. For example, if the woman friends do not participate in agricultural-related activities, they may tend to influence the woman in that direction, therefore, affecting their extent of access to land. Adam et al. (2017) concluded that the social influence from family members or peers is positively related to consumer decisions which in this case, the decisions are with regard to women access and the extent of access to land. 
Table 3: Average Partial Effects and Unconditional average effects of DH model

\begin{tabular}{|c|c|c|c|c|}
\hline \multirow{2}{*}{$\begin{array}{l}\text { VARIABLES } \\
\text { Socio-economic factors }\end{array}$} & \multicolumn{4}{|c|}{ SECOND HURDLE } \\
\hline & CAPE & SE & UAPE & SE \\
\hline Age & -0.001 & 0.003 & -0.000 & 0.002 \\
\hline Spousal age gap & 0.014 & 0.009 & 0.003 & 0.005 \\
\hline Marital status & -0.102 & 0.101 & $-0.269 * * *$ & 0.074 \\
\hline Schooling years & -0.017 & 0.011 & -0.020 & 0.006 \\
\hline Household size & 0.001 & 0.024 & 0.024 & 0.016 \\
\hline Household farm size & $0.424 * * *$ & 0.071 & $0.345 * * *$ & 0.041 \\
\hline Log value of agricultural assets & 0.024 & 0.038 & $0.048 * *$ & 0.018 \\
\hline Log off-farm income & $-0.014 *$ & 0.007 & $-0.013 * * *$ & 0.005 \\
\hline Remittances & $-0.022 * *$ & 0.009 & $-0.012 * *$ & 0.005 \\
\hline \multicolumn{5}{|l|}{ Institutional factors } \\
\hline Market distance & -0.001 & 0.003 & $-0.004 * * *$ & 0.001 \\
\hline Amount of credit & -0.000 & 0.011 & $0.020 * * *$ & 0.007 \\
\hline Extension contacts & 0.041 & 0.043 & $0.061 * * *$ & 0.018 \\
\hline \multicolumn{5}{|l|}{ Social influence } \\
\hline Social influence from family members & 0.068 & 0.045 & $0.103 * * *$ & 0.026 \\
\hline Social influence from friends/peers & $-0.083 * * *$ & 0.031 & $-0.101 * * *$ & 0.020 \\
\hline \multicolumn{5}{|l|}{ Sources of information } \\
\hline Other farmers ${ }^{1}$ & -0.070 & 0.129 & 0.065 & 0.074 \\
\hline Extension agents ${ }^{1}$ & -0.054 & 0.1061 & 0.015 & 0.060 \\
\hline Number of observations & 384 & & & \\
\hline Wald $\operatorname{Chi}^{2}(16)=$ & 271.02 & & & \\
\hline Prob. $>C h i^{2}=$ & 0.000 & & & \\
\hline Log pseudo likelihood & -194.442 & & & \\
\hline
\end{tabular}

Notes: $* * *, * *$, and $*$ indicate the level of significance at $p<0.01,0.05$, and 0.1 , respectively. APE and UAPE stand for Average Partial Effects and Unconditional Average Partial Effects respectively. SE stands for standard errors calculated using the delta method. 1=base category which is farmers' groups.

\section{Conclusion and policy implications}

The first tier of the double hurdle model revealed that the likelihood of women having access to land is positively and significantly influenced by marital status, household size, the value of productive assets, credit borrowed, number of contacts with extension providers, social influence from family members, and use of farmers groups as the main source of information. However, the spousal age gap, distance to the market, and social influence from friends/peers had a negative and significant influence on the likelihood of women having access to land. The extent of women access to land in the second tier was positively influenced by household farm size but negatively influenced by off-farm income, remittances, and social influence from friends/peers.

It is evident that land is a crucial resource for all because of the close relationship between land and livelihoods. Therefore, to improve women access to land, women should have access to credit facilities since credit borrowed increases the capital base of the women farmers thus reducing cash constraints associated with accessing land and farming. The government may assist in the provision of timely and adequate credit facilities to the women farmers on affordable terms so as enhance their access to land. Women farmers should be sensitized on the need to invest in productive agricultural assets so as to improve their bargaining power at the household level and absorb risks associated with farming. Further, women should also be linked conveniently with extension service providers so that they can acquire technical skills and knowledge essential in farming. Through extension service providers, county and national government should come up with campaigns aimed at promoting women access to land, which should target families and societies so as change their beliefs regarding women having access to land. This is because social influence from family members was found to have a significant influence on women access to land. In addition, societies should prohibit early marriages that lead to wider age gaps between spouses thus disempowering women. Therefore, interventions that are geared towards promoting education especially among young girls should be encouraged. This is necessary so as to improve women bargaining power in marriage since education allows further mental development thus, making them assertive and empowered. Moreover, county and national government together with development partners should invest in improving crucial infrastructures and road networks which could enhance women access to input and output markets thus downgrading the transaction costs associated with farming.

Acknowledgments

The authors wish to acknowledge the African Economic Research Consortium (AERC) which is situated in 
Nairobi, Kenya for providing financial support for this research. We are also indebted to the study participants who generously gave of their time and information.

\section{References}

Adams, P., Farrell, M., Dalgarno, B. and Oczkowski, E. (2017). Household Adoption of Technology: The Case of High-Speed Broadband Adoption in Australia. Journal of Technology in Society, 49: 37-47.

Baloch, M. A. and Thapa, G. B. (2016). The Effect of Agricultural Extension Services: Date Farmers' Case in Balochistan, Pakistan. Journal of the Saudi Society of Agricultural Sciences, 1-7.

Burke, W.J. (2009) Fitting and interpreting Cragg's Tobit alternative using Stata. The Stata Journal, 9(4): 584592.

Carroll, J., McCarthy, S. and Newman, C. (2005). An Econometric Analysis of Charitable Donations in the Republic of Ireland. Journal of Economic and Social Review, 36(3): 229-249.

Cragg, J. (1971). Some statistical models for limited dependent variables with application to the Demand for durable goods. Journal of Econometrica, 39: 829-844.

Doss, C., Raney, T., Anríquez, G., Croppenstedt, A., Gerosa, S., Lowder, S., Matuscke, I., Skoet, J. (2011). Role of women in agriculture. ESA working paper number: 11-02. FAO, Rome.

Doss, C., Kovarik, C., Peterman, A., Quisumbing, A. and Bold, M. Van Den. (2015). Gender inequalities in ownership and control of land in Africa: myth and reality. Journal of Agricultural Economics, 46: 1-32.

Eakins, J. (2016). An application of the double hurdle model to petrol and diesel household expenditures in Ireland. Journal of Transport Policy, 47: 84-93.

Food and Agriculture Organization (FAO). (2015). The State of Food Insecurity in the World. Meeting the 2015 international hunger targets: taking stock of uneven progress. Rome, Italy.

Government of Kenya (GoK). (2013). Machakos County Integrated Development Plan 2013-2017. Machakos County: Government publishers, Kenya.

Greene, W.H. (2002). Econometric Analysis (5 $5^{\text {th }}$ edition). New York University: Prentice Hall.

Gyau, A., Faith, A. N., Fondjem-tita, D., Ajaga, N. and Catacutan, D. (2014). Small-holder Farmers Access and Rights to Land: The Case of Njombé in the Littoral Region of Cameroon. Journal of Afrika Focus, 27: 2339.

Hazarika, B., Bezbaruah, P.M. and Goswami, K. (2016). Adoption of modern weaving technology in the handloom micro-enterprises in Assam: A Double Hurdle approach, Journal of Technological Forecasting \& Social Change, 102: 344-356.

Jack, W., Ray, A. and Suri, T. (2013). Transaction Networks: Evidence from Mobile Money in Kenya. Journal of American Economic Review, 103 (3): 356-361.

Jin, S. and Jayne, T. S. (2013). Land Rental Markets in Kenya: Implications for Efficiency, Equity, Household Income, and Poverty. Journal of Land Economics, 89(2): 46-271.

Johnson, N. L., Kovarik, C., Meinzen-Dick, R. Njuki, J. and Quisumbing, A. (2016). Gender, Assets, and Agricultural Development: Lessons from Eight Projects. Journal of World Development, 83: 295-311.

Jones, A. (1989). A double-hurdle model of cigarette consumption. Journal of Applied Economics, 4 (1): $23-39$.

Kassie, M., Ndiritu, S. W. and Stage, J. (2014). What Determines Gender Inequality in Household Food Security in Kenya? Application of Exogenous Switching Treatment Regression. Journal of World Development, 56: $153-171$.

Khalid, A., Nyborg, I. and Nawab, B. (2015). Whose property whose authority? Gendering the legal and customary practices in ownership and access to land: A case of Swat, Pakistan. Journal of Rural Studies, 41: 47-58.

Kikulwe E. M., Fischer .E and Qaim .M. (2014) Mobile Money, Smallholder Farmers, and Household Welfare in Kenya. PLoS ONE, 9(10).

Kirimi, L., Gitau, R. and Olunga, M. (2013). Household Food Security and Commercialization among smallholder farmers in Kenya. A paper presented at the 4th International Conference of the African Association of Agricultural Economists. Nairobi, Kenya.

Kenya National Bureau of Statistics. (2017). Statistical Abstract. Kenya Bureau of Statistics Publishers (KNBS). Nairobi, Kenya.

Kritz, M. M. and Adebusoye, P.M. (1999). Determinants of Women's Decision-Making Authority in Nigeria: The Ethnic Dimension. Journal of Sociological Forum, 14(3): 399-424.

Lambrecht, I. B. (2016). “As a Husband I Will Love, Lead, and Provide”. Gendered Access to Land in Ghana. Journal of World Development, 88: 188-200.

MacKenzie, S. B., Podsakoff, P. M., Podsakoff, N. P. (2011). Construct measurement and validation procedures in MIS and behavioral research: Integrating new and existing techniques. MIS Quarterly, 35(2):293-334.

Mathenge, M., Smale, M. and Olwande, J. (2014). The Impacts of Hybrid Maize Seed on the Welfare of Farming Households in Kenya. Journal of Food Policy, 44:262-271. 
Meinzen-dick, R., Quisumbing, A., Behrman, J., Biermayr-jenzano, P., Wilde, V., Noordeloos, M., Ragasa C. and Beintema, N. (2010). Engendering Agricultural Research. International Food Policy Research Institute Discussion Paper 00973. Washington, DC.

Menale. K., Zikhali, P., Pender, J. and Kohlin, G. (2010). The Economics of Sustainable Land Management Practices in the Ethiopian Highlands. Journal of Agricultural Economics, 61: 605-627.

Menon, N., Rodgers, M. and Nguyen, H. (2014). Women's Land Rights and Children's Human Capital in Vietnam. Journal of World Development, 54: 18-31.

Mishra, K. and Sam, A. G. (2016). Does Women's land ownership promote their empowerment? Empirical Evidence from Nepal. Journal of World Development, 78: 360-371.

Muraoka, R., Jin, S. and Jayne, T. S. (2014). Land Access, Land Rental, and Food Security: Evidence from Kenya. Paper presented at the Agricultural and Applied Economics Association (AAEA) 2014 Annual Meeting, Minneapolis.

Mutlu, S. and Gracia, A. (2006). Spanish food expenditure away from home (FAFH) by type of meal. Journal of Applied Economics, 38(9): 1037-1047.

Muyanga, M., Jayne, T. S. (2014). Effects of rising rural population density on smallholder agriculture in Kenya. Journal of Food Policy, 48: 98-113.

Ndiritu, S. W., Kassie, M. and Shiferaw, B. (2014). Are there systematic gender differences in the adoption of sustainable agricultural intensification practices? Evidence from Kenya. Journal of Food Policy, 49: 117127.

Newman, C., Henchion, M. and Matthews, A. (2003). A double-hurdle model of Irish household expenditure on prepared meals. Journal of Applied Economics, 35(9): 1053-1061.

Odoemelam, L. E., Alamba, C. and Lekan-Akomolafe, C. N (2014). Evaluation of Women Access and Rights to Land and its Implications on Rural Household Food Security in Selected Rural Communities, Abia State, Nigeria. Journal of Agriculture and Food Sciences, 2(8): 235-241.

Pudney, S. (1989) Modeling Individual Choice: The Econometrics of Corners, Kinks and Holes. Blackwell Publishing, Massachusetts, USA.

Rao, E. J. and Qaim, M. (2011). Supermarkets, farm household income, and poverty: Insights from Kenya. Journal of World Development, 39(5):784-796.

Tobin, J. (1958) Estimation of relationships for limited dependent variables. Econometrica,

26: 24-36.

Woldeyohanes, T., Heckelei, T. and Surry, Y. (2016). Effect of Off-farm Income on Smallholder Commercialization: Panel Evidence from Rural Households in Ethiopia. Journal of Agricultural Economics, 48: $1-12$.

World Bank. (2012). Gender equality and Development. World Development Report. The International Bank for Reconstruction and Development, World Bank Group. Washington DC, USA.

Zaki, J., Schirmer, J. and Mitchell, J. P. (2011). Social influence modulates the neural computation of value. Journal of Psychological Science, 22: 894-900. 


\section{Appendices}

Appendix 1: Description of variables used in the Double Hurdle model

\begin{tabular}{|c|c|}
\hline Variables & Description of the variables \\
\hline \multicolumn{2}{|l|}{ Dependent Variables } \\
\hline Access & Whether a woman has access to land or not (dummy). \\
\hline The extent of access to land & Size of land accessed by women (Acres). \\
\hline \multicolumn{2}{|l|}{ Independent variables } \\
\hline Age & Age of the woman (years) \\
\hline Spousal age gap & The age gap between married couples (years) \\
\hline Marital status & Dummy $=1$ if the woman is married, 0 otherwise \\
\hline Schooling years & The education level of the woman (Schooling years) \\
\hline Household size & The number of household members in the household \\
\hline Household farm size & Total household farm size (acres) \\
\hline Agricultural assets & Value of assets that the woman owns/controls (KES) \\
\hline Off-farm income & $\begin{array}{l}\text { Woman non-farming income derived from other sources apart from farming } \\
\text { (KES) }\end{array}$ \\
\hline Remittances & Amount of remittance received by the woman in the last one year (KES) \\
\hline Market distance & Proximity to the nearest input/output market (Walking minutes) \\
\hline Amount of credit & The amount of credit borrowed in the last 3 years (KES) \\
\hline Extension contacts & $\begin{array}{l}\text { The number of contacts with extension service providers in a year } \\
\text { (continuous) }\end{array}$ \\
\hline Social influence & $\begin{array}{l}\text { Answered and evaluated using } 7 \text { items with a } 5 \text {-point Likert scale. } 1=\text { strongly } \\
\text { disagree, } 2=\text { Disagree, } 3=\text { Neutral, } 4=\text { Agree and } 5=\text { strongly agree }\end{array}$ \\
\hline Sources of information & Sources of agricultural information \\
\hline Other farmers & Dummy $=1$ if the woman got information from other farmers, 0 otherwise \\
\hline Farmers group & Dummy $=1$ if the woman got information from a farmers' group, 0 otherwise \\
\hline Extension agents & $\begin{array}{l}\text { Dummy }=1 \text { if the woman got information from extension agents } \\
\text { (government/private), } 0 \text { otherwise }\end{array}$ \\
\hline
\end{tabular}

Appendix 2: Factor analysis for describing social influence constructs

\begin{tabular}{|c|c|c|c|c|c|c|}
\hline Constructs & & Items & $\begin{array}{l}\text { Factor } \\
\text { Loadings }\end{array}$ & $C R$ & $A V E$ & Kmo \\
\hline \multirow[t]{7}{*}{$\begin{array}{l}\text { Social } \\
\text { influence }\end{array}$} & 1. & $\begin{array}{l}\text { Those in my social circle think I (the } \\
\text { woman) should have access to land. }\end{array}$ & 0.8684 & & & \\
\hline & 2. & $\begin{array}{l}\text { Our family members think I should have } \\
\text { access to land. }\end{array}$ & 0.9174 & & & \\
\hline & 3. & $\begin{array}{l}\text { Our relatives think I should have access to } \\
\text { land. }\end{array}$ & 0.8706 & & & \\
\hline & 4. & $\begin{array}{l}\text { Our friends think I should have access to } \\
\text { land. }\end{array}$ & 0.8927 & & & \\
\hline & 5. & $\begin{array}{l}\text { People who are important to me think that I } \\
\text { should have access to land. }\end{array}$ & 0.9484 & & & \\
\hline & 6. & $\begin{array}{l}\text { People who influence my behavior think I } \\
\text { should have access to land. }\end{array}$ & 0.9093 & & & \\
\hline & 7. & $\begin{array}{l}\text { My peers at work think I should have access } \\
\text { to land }\end{array}$ & 0.9443 & 0.9059 & 0.6392 & 0.8436 \\
\hline
\end{tabular}

Appendix 3: White test results for heteroskedasticity

\begin{tabular}{lrrl}
\hline Source & \multicolumn{1}{c}{$c h i^{2}$} & Df & P-values \\
\hline Heteroskedasticity & 277.41 & 205 & 0.001 \\
Skewness & 71.46 & 19 & 0.000 \\
Kurtosis & 4.48 & 1 & 0.034 \\
Total & 353.35 & 225 & 0.000 \\
\hline
\end{tabular}


Appendix 4: Variance inflation factor test results for multicollinearity

\begin{tabular}{lll}
\hline Variable & VIF & 1/VIF \\
\hline Schooling years & 1.66 & 0.601 \\
Age of the respondent & 1.62 & 0.617 \\
Log of remittances & 1.50 & 0.666 \\
Extension contacts & 1.43 & 0.702 \\
Log of the amount of credit & 1.41 & 0.710 \\
Log of off-farm income & 1.29 & 0.777 \\
Household farm size & 1.28 & 0.782 \\
Spouse age gap & 1.20 & 0.836 \\
Log of the value of agricultural assets & 1.18 & 0.846 \\
Household size & 1.13 & 0.885 \\
Social influence from family members & 1.12 & 0.895 \\
Market distance & 1.11 & 0.904 \\
Social influence from friends & 1.07 & 0.934 \\
Mean VIF & 1.31 & \\
\hline
\end{tabular}

Note: VIF values were less than 10 thus there was no serious linear relationship among the continuous variables used in the analysis.

Appendix 5: Pairwise correlation coefficients for a categorical variable

\begin{tabular}{lll}
\hline & Marital status & Sources of agricultural information \\
\hline Marital status & 1.0000 & \\
Sources of agricultural information & 0.0039 & 1.0000 \\
\hline
\end{tabular}

Note: Pairwise correlation coefficients were less than 0.75 , therefore there was no serious linear relationship between the categorical variables used in the analysis. 